\title{
Orthopaedie: blijft in beweging
}

Citation for published version (APA):

Walenkamp, G. H. I. M. (2007). Orthopaedie: blijtt in beweging. Maastricht University. https://doi.org/10.26481/spe.20071102gw

Document status and date:

Published: 02/11/2007

DOI:

10.26481/spe.20071102gw

Document Version:

Publisher's PDF, also known as Version of record

\section{Please check the document version of this publication:}

- A submitted manuscript is the version of the article upon submission and before peer-review. There can be important differences between the submitted version and the official published version of record.

People interested in the research are advised to contact the author for the final version of the publication, or visit the DOI to the publisher's website.

- The final author version and the galley proof are versions of the publication after peer review.

- The final published version features the final layout of the paper including the volume, issue and page numbers.

Link to publication

\footnotetext{
General rights rights.

- You may freely distribute the URL identifying the publication in the public portal. please follow below link for the End User Agreement:

www.umlib.nl/taverne-license

Take down policy

If you believe that this document breaches copyright please contact us at:

repository@maastrichtuniversity.nl

providing details and we will investigate your claim.
}

Copyright and moral rights for the publications made accessible in the public portal are retained by the authors and/or other copyright owners and it is a condition of accessing publications that users recognise and abide by the legal requirements associated with these

- Users may download and print one copy of any publication from the public portal for the purpose of private study or research.

- You may not further distribute the material or use it for any profit-making activity or commercial gain

If the publication is distributed under the terms of Article $25 \mathrm{fa}$ of the Dutch Copyright Act, indicated by the "Taverne" license above, 
Orthopaedie: Blijft in beweging 


\section{Colofon}

Ontwerp en print: Océ Business Services, Maastricht

ISBN: 978-90-5681-277-5

NUR: 870

Alle rechten voorbehouden. Niets uit deze uitgave mag worden verveelvoudigd, opgeslagen in een geautomatiseerd gegevensbestand of openbaar gemaakt worden, zonder voorafgaande schriftelijke toestemming van de auteur of uitgever. 


\section{Orthopaedie: Blijft in beweging}

Inaugurale rede

uitgesproken bij de aanvaarding van het ambt van

hoogleraar Orthopaedie aan de Universiteit van Maastricht

op vrijdag 2 november 2007

door

dr. G. H. I. M. Walenkamp

Maastricht University 

Mijnheer de rector Magnificus, dames en heren,

\section{Inleiding}

Een inaugurale rede is traditiegetrouw het eerste, en openbaar toegankelijke college van de nieuwe hoogleraar die zich daarbij aan de universitaire gemeenschap en vooral aan de studenten bedoelt voor te stellen. Er wordt een overzicht van het vakgebied gepresenteerd en de nieuwbakken ordinarius gebruikt een aantal belangrijke onderwerpen om de studenten van zijn eigen kwaliteiten en van het belang van zijn vak te overtuigen.

Bij de oprichting van de Universiteit van Maastricht werd echter het hoorcollege afgeschaft, en aan de meer actieve vorm van Probleem Geörienteerd Onderwijs (PGO) de voorkeur gegeven. U moet nu dus eigenlijk opgesplitst worden in onderwijsgroepen van ongeveer 10 personen, en een 20-tal onderwijskamers opzoeken. Aan de hand van sappige casuïstiek moet $U$ vervolgens kennis verwerven van de orthopaedie.

Omdat dit nu wat onpraktisch is, wil ik $U$ het vakgebied toch maar op zogenaamd frontale wijze en in deze zaal presenteren. Aan de hand daarvan kunt $U$ dan zelf hopelijk concluderen hoezeer Orthopaedie inderdaad een mooi en nuttig vak is, omdat het zorgt dat $U$ zo lang mogelijk moeiteloos kunt blijven bewegen. Ik wil beginnen proberen te formuleren wat de Orthopaedie behelst, en daarbij ook iets ingaan op de grensgebieden

\section{Inhoud en grensgebieden van het vakgebied}

De orthopedie omvat als vakgebied de diagnostiek, preventie en de behandeling van aangeboren en verworven ziekten en letsels van het bewegingsapparaat. De orthopaed houdt zich dan ook bezig met de onderdelen ervan: bot, kraakbeen, gewrichten, spieren, en pezen, en gebruikt technieken ter reparatie, regeneratie, en ook in toenemende mate vervanging van deze weefsels.

Wat maakt het vak dan tot een apart vak ? Tot op zekere hoogte creëert de opleiding tot orthopaed het vak. Het zijn de opleidingseisen, mede door orthopaeden zelf geformuleerd, die bepalen wat de assistent in opleiding moet leren. Er is daarbij dus sprake van enige self-fulfilling prophecy: het vak maakt het vak zelf.

Maar wat maakt dan iemand tot dat, wat wij als orthopaeden een echte orthopaed vinden ? Een orthopaed houdt zich "full time" 
bezig met het bewegingsapparaat. Daarmee is echter iemand die zich bezig houdt met het bewegingsapparaat nog geen orthopaed. De gemiddelde leek heeft bovendien vaak niet zo goed een idee wat nu het bewegingsapparaat (BA) eigenlijk is, en laat staan dus wat een orthopaed is. Wij sommen desgevraagd dan de genoemde weefsels maar op waaruit het BA bestaat, en we hebben het over armen, benen en rug. En dan nòg hebben we op feestjes en partijen vaak moeite om uit te leggen wat we dan precies doen.

Het lijkt me dat het bijzondere van het vakgebied Orthopaedie vooral is, dat het zich steeds nadrukkelijk richt op de vaak in de verre toekomst gelegen situatie, en een behandelstrategie uitzet die meestal tientallen jaren beslaat, vaak levenslang. Dat langere termijn denken is niet uniek, maar wellicht wel de mate ervan en het is wel wezenlijk voor ons vak.

Horen orthopaeden dan tot de electieve groep van "beschouwende denkers" of zijn het ook "doeners"? Zijn we orthopaeden of orthopaedisch chirurgen ? Welnu, we willen beiden zijn, en de evenwichtige combinatie van wel en niet opereren hoort het resultaat te zijn van een opleiding die specifiek op dat evenwicht gericht is.

Enkele klassieke voorbeelden maken duidelijk wat als typisch gezien zou kunnen worden voor orthopaedisch handelen.

Deformiteiten van het bewegingsapparaat die aangeboren zijn of later ontstaan, kunnen leiden tot klachten van pijn en bewegingsbeperkingen in de toekomst. Dat is met name het geval als er een scheve belasting bestaat op de gewrichten. Er is geen ingewikkelde mechanische berekening nodig om in te zien dat $\mathrm{X}$ of $\mathrm{O}$ benen een overbelasting geven van de binnenste of buitenste helft van de knie (figuur 1).

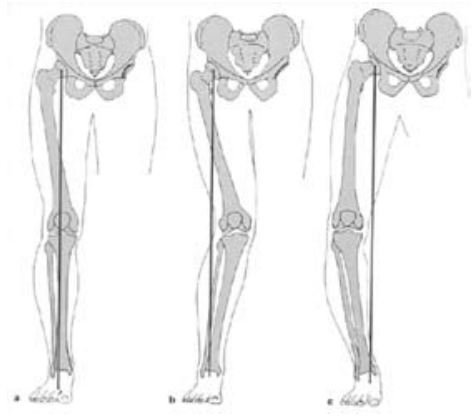

Figuur 1: De as van belasting op de rechter knie, getekend in een recht been (a), een X-been (b) en een O-been (c). In geval van een afwijkende belastings-as ontstaat verhoogde druk in de buitenste helft (b) of binnenste helft (c) van de knie, waardoor daar een verhoogde kans op artrose bestaat. 
De grens van belastbaarheid van het kniekraakbeen wordt in zo'n geval geleidelijk overschreden in de loop van de jaren, en hoe schever hoe eerder. Er kan een artrose ontstaan. Een orthopaed zal, als hij voldoende van dat beschouwend vermogen heeft, zich proberen voor te stellen hoe snel dat zal gebeuren en hoeveel klachten dat op welk moment zal geven bij een specifieke patiënt. Hij (of uiteraard ook: zij) zal vervolgens een timing van maatregelen voorstellen die het ontstaan van artrose zal proberen te voorkomen of te vertragen. Op een gegeven moment, als de niet-operatieve maatregelen onvoldoende helpen, kan met een operatie tijdig een correctie van de stand aan gebracht worden. Er gebeurt dan precies wat ook wezenlijk voor Orthopaedie is: recht maken wat krom is. Met een osteotomie (een operatie waarbij een bot wordt doorgezaagd) kan het bot zodanig gefixeerd worden dat de afwijking van de been-as wordt opgeheven.

In bepaalde fasen van de behandeling, nog vóórdat een operatie nodig is, kan een uitwendige brace bij de behandeling van artrose behulpzaam zijn, door de druk op een artrotische helft van een knie te verminderen. Dit is vergelijkbaar met de toepassing van een brace bij de behandeling van wervelkolomverkrommingen. Bij het nog groeiende kind wordt door de combinatie van de groei en de constante druk door een brace de verkromming geleidelijkaan gecorrigeerd (figuur 2).

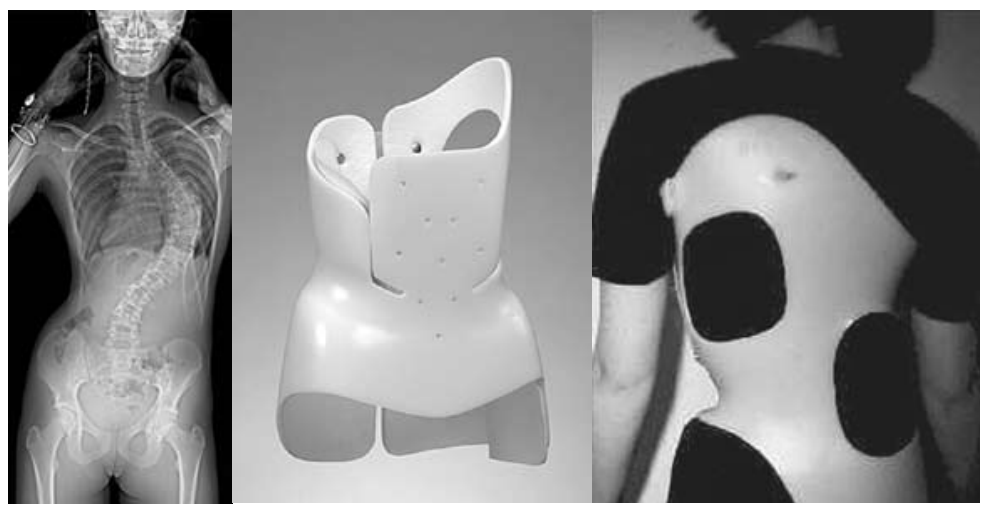

Figuur 2: Een verkromming van de wervelkolom (scoliose) (röntgenfoto links) wordt behandeld met een kunststof brace (midden), die tijdens de groei de verkromming tracht te verminderen door continue druk op de top van de deformiteit (rechts) 
We zijn dan precies bij wat velen van $U$ als de klassieke Orthopaedie herkennen. Inderdaad is het beeldmerk van de Orthopaedie sinds Nicolas Andry in 1741 een boom waarbij tijdens de groei een verkromming wordt gecorrigeerd door stevige vastsnoering tegen een rechte paal (figuur 3).

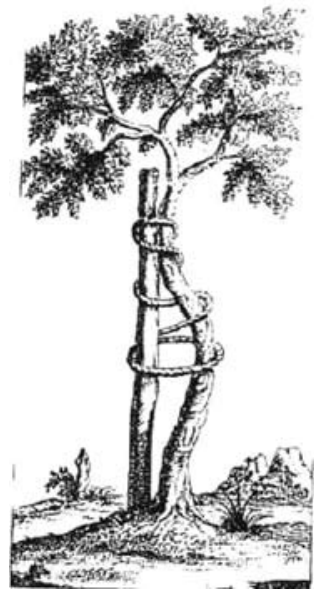

Figuur 3: Eenzelfde principe kan worden toegepast op een groeiende boom: het logo van de Orthopaedie.

Het is van veel Orthopaedische afdelingen en tijdschriften een onderdeel van het logo geworden.

Orthopaeden zijn meestal echte knutselaars die het leuk vinden om te opereren, net als de meeste andere chirurgen. Een niet operatieve behandeling is dan ook vaak minder leuk en niet zo uitdagend, maar is om diverse redenen vaak toch moeilijker. Doordat in toenemende mate haast en ongeduld bepalend worden in diagnostiek en behandeling wordt vaak de voorkeur aan een operatie gegeven Dat de niet operatieve behandeling ook wel conservatief wordt genoemd, of zelfs "koude" Orthopaedie geeft aan dat niet operatieve behandeling als ouderwets en niet vernieuwend wordt ervaren: het is niet "cool". Het is echter doorgaans veeleisender, moeilijker en complexer. Het verdient ook in de opleiding meer aandacht. In het kader van het nieuwe en zeer gestructureerde opleidingsplan voor assistenten Orthopaedie is een 64 - tal orthopaedische standaard behandelingen (OSB's) gedefinieerd waarvan op het einde van de opleiding een 50 -tal goed moet kunnen worden uitgevoerd. Van deze 64 OSB's zijn 26 acute letsels of fracturen. 
Hier wordt dus zoals aangegeven het vak gemaakt door het vak. Het totale aantal conservatieve behandelingen waaruit kan worden gekozen is veel minder dan het aantal operatieve behandelingen: 16 versus 48 . Het is dus de vraag of deze verhouding niet onevenwichtig is.

Orthopaedie vereist dus, naast een grondige kennis van de anatomie van het bewegingsapparaat, en een vermogen tot lange termijn-denken, ook een ruime ervaring in zowel de conservatieve als de operatieve beïnvloeding ervan. Een verstandige attitude met een delicate balans tussen conservatieve en operatieve geneeskunde, tussen afwachten en aanvallen, tussen beschouwen en doen.

Een beschrijving van het vakgebied houdt ook de afgrenzing in ten opzichte van andere, verwante vakgebieden. Het gaat dan vooral om andere disciplines diezich meer ofminderook methet bewegingsapparaat bezig houden. Er is een behoorlijke overlap met reumatologen (artrose), revalidatie artsen (“RSI",prothesen, orthesen), neurochirurgen (hernia, perifere zenuw inklemmingen), plastisch chirurgen (handchirurgie), anesthesisten (pijnbehandeling bewegingsapparaat) en de algemeen chirurg - traumatologen (fracturen). Op deze grensgebieden zijn nogal eens verwoede discussies gevoerd, maar die zijn afhankelijk van vooral persoonlijke contacten gelukkig doorgaans opgelost in goede harmonie. Meestal wordt door artsen en patiënten snel genoeg gezien waar de ervaring het grootst is. Wij als orthopaeden claimen geen bewegingsapparaat, maar wel dat we bijzondere kennis en vaardigheden hebben in zowel de conservatieve als operatieve behandeling ervan

Ik wil hier specifiek ingaan op een relevant grensgebied, namelijk de fractuurbehandeling. Daarbij is een lichte terugblik behulpzaam.

\section{Orthopaedie en traumatologie}

Allereerst heeft de Orthopaedie zich als zelfstandig vakgebied niet uit de heelkunde ontwikkeld, alhoewel dat soms wel wordt gesteld. In feite is de samenstelling van de groep van 21 artsen die bijeenkwamen in 1898 om de Nederlandse Orthopaedische Vereniging op te richten een illustratie van de wortels van het vakgebied: 12 conservatieve orthopaeden, 6 algemeen chirurgen en 3 algemeen artsen. De toevoeging aan de naam "Vereniging van artsen ter beoefening van orthopaedie, mechanotherapie, geneeskundige gymnastiek en massage" werd na 1915 geschrapt. De belangrijkste reden voor de oprichting van de vereniging was namelijk dat men zich in het begin wilde onderscheiden van niet artsen, met name heilgymnasten en masseurs. Immers tot dan werden 
bewegingsapparaat klachten slechts met heilgymnastiek behandeld en werd de opkomst in Europa en met name Nederland van de zogenaamde "Zander instituten" door artsen betreurd (1). Dat waren de sportscholen van toen: gebruik van veel apparatuur en begeleiding door masseurs. De heilgymnastiek instituten hadden een haast industriële aanpak, die patiënten lieten oefenen en masseren met behulp van een groot aantal apparaten, aangedreven door een stoommachine die in een aangrenzende kamer stond (figuur 4). In Nederland bestonden rond de eeuwwisseling een tiental Zander-instituten, waarvan de laatste sloot in 1939 in Rotterdam (4).

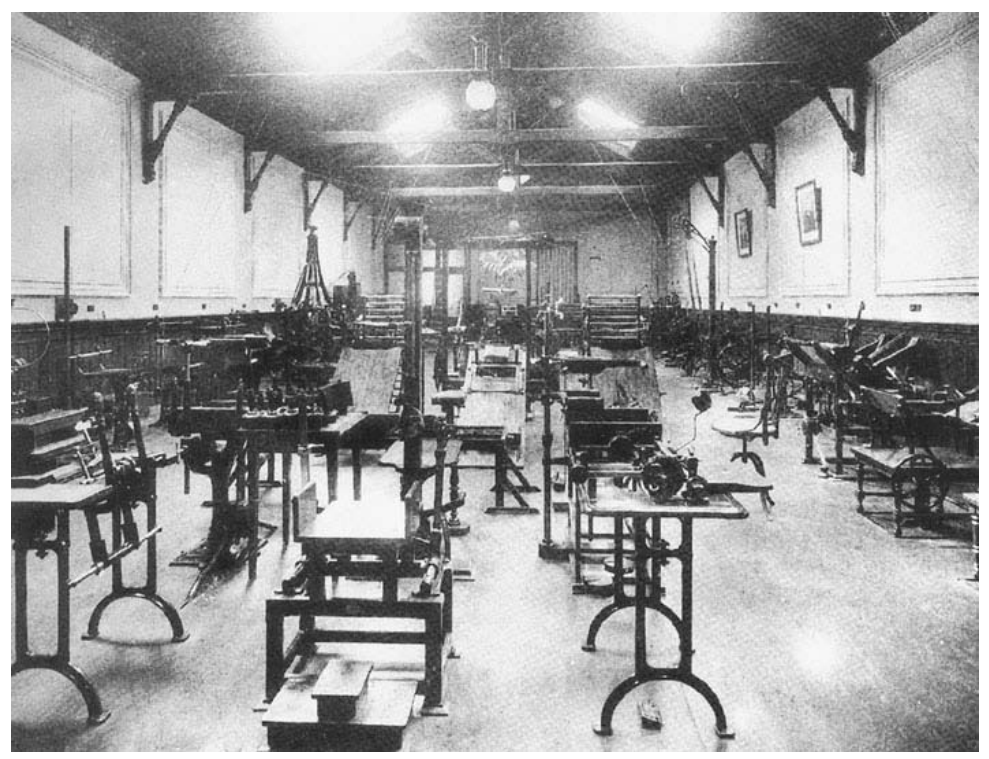

Figuur 4a: Interieur van het Zanderinstituut in Rotterdam in 1920. De gelijkenis met de huidige sportscholen ligt voor de hand.(4) 


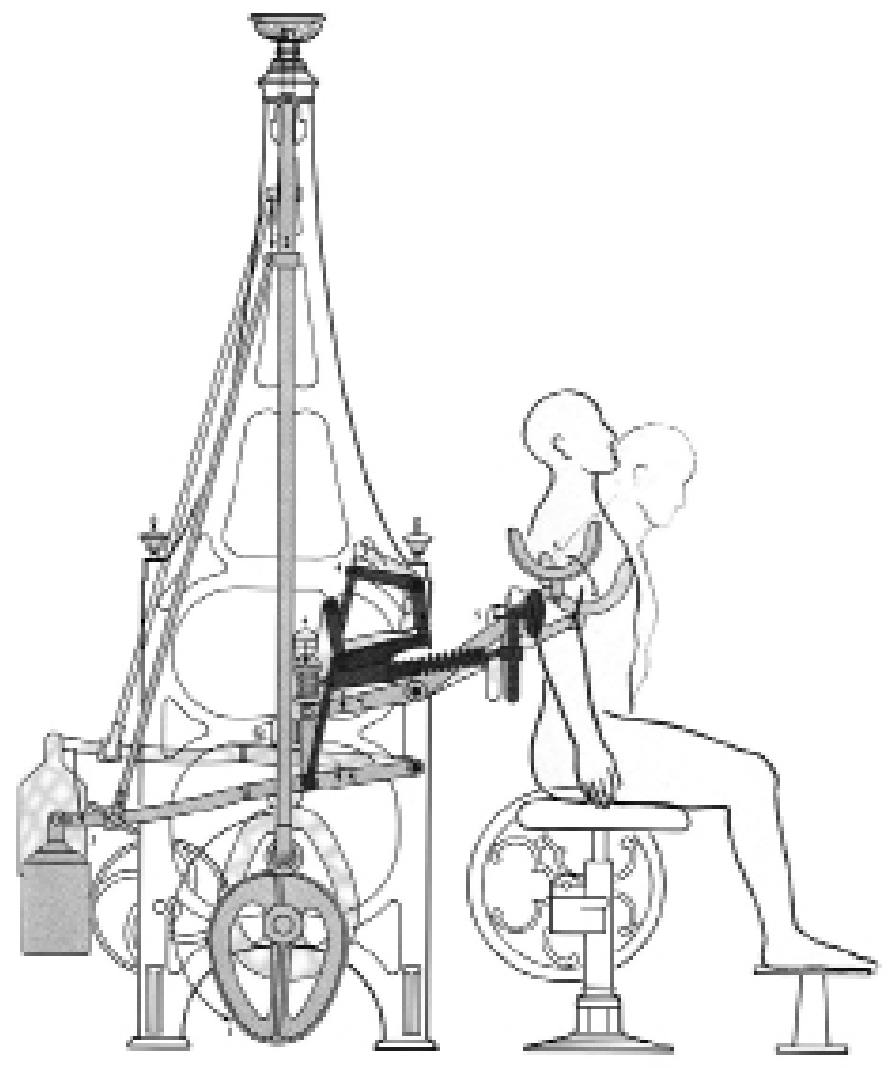

Figuur 4b: Dit toestel E6 wordt beschouwd als het "pièce de résistance" van de gehele collectie Zander apparaten in het Boerhaave Museum. Het is bedoeld om via passieve ademhaling de borstkas te verwijden en de bloedcirculatie in de longen te bevorderen. Twee okselsteunen bewegen evenals een rugkussentje ritmisch op en neer, aangedreven door een drijfriem.De omvang van de beweging kon nauwkeurig ingesteld worden.(4)

De uitgroei in het begin van de $20 e$ eeuw van het vak Orthopaedie tot zelfstandig specialisme in Nederland is steeds gepaard gegaan met discussie over juist het fractuur grensgebied en die discussie spitste zich met name toe in de academische centra. Vooral na de tweede wereldoorlog loopt de discussie over de traumatologie in Nederland erg op, net zoals -en parallel aan- die over de academisering van het vakgebied $(1,3)$.

In de lokale en landelijke discussies waren de argumenten van chirurgische zijde vooral dat de orthopaed niet deskundig was in de 
behandeling van verse fracturen, terwijl orthopaeden op hun beurt aangaven de hele dag met het BA bezig te zijn. Qua argumenten lijkt er dus niet veel nieuws onder de zon.

In de jaren '80 echter groeiden de traumatologische disciplines binnen de Heelkunde en de Orthopaedie naar elkaar toe. Goede contacten op de werkvloer en gezamenlijke congressen waren effectiever dan polariserende uitspraken. In 1989 werd een convenant gesloten tussen beide wetenschappelijke verenigingen waarin ook in nietopleidingsziekenhuizen de onderlinge samenwerking werd geregeld. Die regeling is sindsdien hernieuwd en aangepast (1999, 2004, 2007). Kernpunt hierin is steeds dat de behandeling van acute, niet-verwezen letsels ten gevolge van een trauma van het BA door beide disciplines in volle omvang dient te geschieden, ook in geval van polytrauma patiënten. Voor beide disciplines geldt daarbij dat een minimum participatie in tijd van $20 \%$ moet bestaan, om de opleiding en expertise te waarborgen.

Het is te betreuren dat patiënten van deze verdeling meestal niet op de hoogte zijn, en vaak verrast worden als ze zich met een fractuur op een EHBO melden. Meer openheid en voorlichting over de bij leken onbekende afspraak over de wijze van fractuurverdeling is dringend gewenst, en het vaag in het midden laten is niet meer van deze tijd.

Van belang is verder, dat de convenanten en samenwerkingsverbanden steeds gaan over de acute letsels. Chronische letsels van het BA, ook als die posttraumatisch zijn, blijven onverkort het gebied waar de Orthopaed zich bij uitstek kennis, attitude en vaardigheden heeft verworven.

Als ideale traumatologische situatie zie ik, ook gezien de verwarring in de richting van patiënten, een gecombineerde Trauma afdeling, net zoals Albert van Kampen in 2002 aangaf bij de aanvaarding van zijn leerstoel in de Orthopaedische Traumatologie in Nijmegen (8). Daarin zouden zowel orthopaedische als heelkundige traumatologen moeten participeren, en ieder zijn specifieke deskundigheid inbrengen. Competitie maakt plaats voor samenwerking en kwaliteit is de enige drijfveer. In Maastricht is het nodig te komen tot een betere samenwerkingsvorm. Wij hopen met de heelkundige traumatologische groep onder leiding van prof. Peter Brink te kunnen komen tot een geleidelijke uitbreiding van onze samenwerking waarin respect voor ieders specifieke inbreng de leidraad moet zijn. Wellicht kunnen we gezamenlijk de zorg voor de patiënten met heupfracturen in een zorglijn structureren. Deze patiëntengroep van meestal zwakke ouderen is net als veel andere fractuur operaties te vaak sluitpost in de acute zorg, en dat moet snel beter kunnen. 
Traumatologie vormt doorgaans niet het grootste deel van het orthopaedische werk. Bij een verder exposé van het vakgebied zou ik een keuze willen maken, gebaseerd op mijn nu bijna 40 jarige rondtocht. Ik mocht immers destijds al beginnen als geïnteresseerd student in een Bredase perifere praktijk van een gastvrije en bijzonder orthopaed: Theo Smithuis (1924-2006). Van toen en daar leidt mijn orthopaedisch pad rechtstreeks naar nu en hier.

De mogelijkheden, maar vooral ook de onmogelijkheden van het vak worden het best geilllustreerd door de bespreking van enerzijds vaak voorkomende, dagelijkse klachten van het BA, en anderzijds door in te gaan op hedendaagse high tech toepassingen. Ik wil $U$ van beide aspecten voorbeelden geven.

\section{“Dagelijkse" ziekten van het bewegingsapparaat}

Klachten van het BA zijn zeer frequent, maar frequente klachten behoeven niet altijd specialistische zorg. Daarmee beweegt de diagnostiek en behandeling van BA aandoeningen zich uitgebreid op een ander interessant grensgebied: dat der huisartsgeneeskunde. Bij de huisarts horen klachten van het BA tot de top-drie in de dagelijkse praktijk. De vakgroep Orthopaedie heeft al lang en intensief met de eerste lijn samengewerkt. Niet alleen in een brainstormgroep als de stuurgroep $1 e$ - ze lijn, maar ook bij het eerste en toen grensverleggende transmurale onderzoek naar de consultatie van de specialist in de 1e lijn.

Op basis van gegevens uit huisarts-zorgregistraties vinden we in het "Nationaal Kompas Volksgezondheid" dat in Nederland artrose en vooral ook nek- en rugklachten zeer frequent voorkomen (10) (16). De cijfers voor de incidentie (aantal nieuwe gevallen per jaar) zijn voor artrose de afgelopen jaren redelijk stabiel: 24.000 mannen en 54.000 vrouwen. Echter de prevalentie (het totale aantal personen) in Nederland van personen ouder dan 55 jaar met artrose is nu circa 200.000 mannen en 425.000 vrouwen, en dit getal zal gezien de vergrijzing in 2020 bijna met $40 \%$ gestegen zijn. Een maat voor de gezondheid die door een ziekte verloren gaat kan worden uitgedrukt in zogenaamde "Disability Adjusted Life Years" waarin de verloren prettige jaren worden berekend in combinatie met de ernst van de ziekte. Artrose scoort in de groep met het hoogste verlies in deze gezondheidsmaat (9).

In een enquête die door het Nipo zojuist in september gehouden werd, en in oktober aan de Orthopaeden gepresenteerd, gaf ruim $60 \%$ van de ondervraagden aan het laatste half jaar beperkingen te 
hebben ondervonden bij hun functie van het BA. Bij $80 \%$ van hen ging dat gepaard met veel pijn. Het dagelijks functioneren wordt zoals verwacht gehinderd, en dan vooral in het huishouden. Eenderde heeft ernstige beperkingen in sociaal contact, en dit laatste vinden de meeste ondervraagden ook het meest bedreigend. Van belang is dat verder van de Nederlanders ouder dan 65 jaar bijna 25\% door hun BA klachten niet meer kan werken. Van de beroepsbevolking geeft niet minder dan 1,5 miljoen (van de 7,1 miljoen) personen aan niet tot zijn 65ste te kunnen werken door bewegingsproblemen (15). Als het belang van een vakgebied aan de hand van deze getallen mag worden berekend, blijkt Orthopaedische hulp dus hoog te scoren, ook als in aanmerking wordt genomen dat veel klachten, met name in het begin in de eerste lijn kunnen worden behandeld.

In het advies dat de Raad voor Gezondheidsonderzoek (RGO) voor de minister in 2006 heeft opgesteld over de onderzoeksagenda in de medische biotechnologie is geadviseerd BA aandoeningen als een van de drie topprioriteiten voor onderzoek aan te merken, en dan met name artrose (12). Tot ons genoegen wordt dit onderschreven in de meest recente beleidsnota over onderzoek en topreferente zorg aan faculteit en ziekenhuis (6). De medewerkers in onze artrose onderzoekslijn werken hard en ook vruchtbaar onder leiding van Lodewijk van Rhijn aan de vertaalslag van deze keuzes en wensen. Onze afdeling heeft immers een lange onderzoekstraditie naar de basale en therapeutische aspecten van artrose. Onze Artrose Kliniek Maastricht, opgezet door Mike van Steijn, is de vertaling ervan in de gezondheidszorg. We verwachten de komende jaren dit te kunnen uitbouwen tot een efficiënte en vruchtbare zorglijn en topreferente functie Artrose.

De impact die BA klachten vooral op het grensgebied met de eerste lijnszorg hebben, zijn de oorzaak van mijn interesse in "dagelijkse ziekten" ( "common diseases") in de orthopaedie. Het is uitdagend en heel goed mogelijk om zonder sophisticated apparatuur BA klachten te onderzoeken en te behandelen, ook in de tweede lijn.

Dagelijkse ziekten worden vaakalszogewoon beschouwd datten onrechte verondersteld wordt dat onderzoek ernaar nauwelijks nodig is (7) (13). Het is echter juist een uitdaging bij het kiezen van een onderzoeksonderwerp en het bedenken van een studieopzet te streven naar hoge relevantie in het palet van zeer dagelijkse ziekten. Een paar voorbeelden. 
In de jaren '80 is door Jan Verhaar in Maastricht een Randomised Trial uitgevoerd naar de behandeling van de tennisarm (figuur 5), waarbij vooral op korte termijn een injectie met cortison veel effectiever was dan een gespecialiseerde fysiotherapeutische behandeling (17).
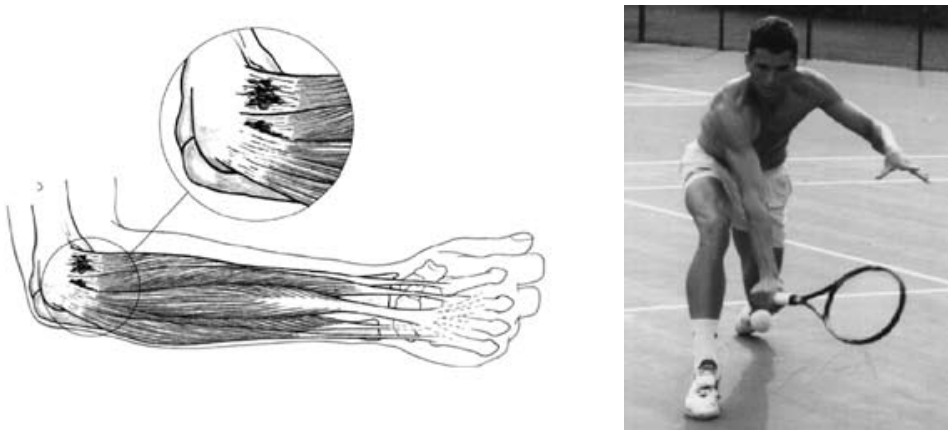

Figuur 5: Tennisarm: degeneratieve afwijkingen bij de aanhechting van de pols- en vingerstrekkers veroorzaken pijn in de elleboog bij geforceerd strekken van de pols, zoals hier hopelijk niet het geval is bij een bekend Nederlands toptennisser.

Even frequent en relevant zijn schouderklachten veroorzaakt door kapsel en slijmbeurs problemen. Op het ogenblik wordt in Maastricht in een patiëntgebonden onderzoek het nog steeds ontbrekende bewijs verzameld of cortison bij de injecties als toevoeging noodzakelijk is (figuur 6).

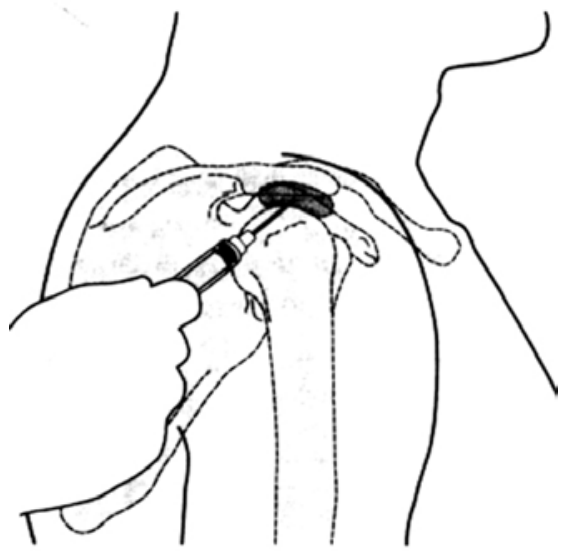

Figuur 6: Schema van een injectie in de slijmbeurs boven het schoudergewricht. Meestal wordt een combinatie gebruikt van verdoving met cortison 
Als er tot slot één onderwerp is dat soms badinerend wordt gebruikt om orthopedie als een suf vak te kenmerken dan zijn het wel steunzolen. Ik geef toe dat ik in mijn opleiding heb geleerd hoe ik de toen metalen steunzolen leerde bijkloppen op een klomp lood (figuur 7).

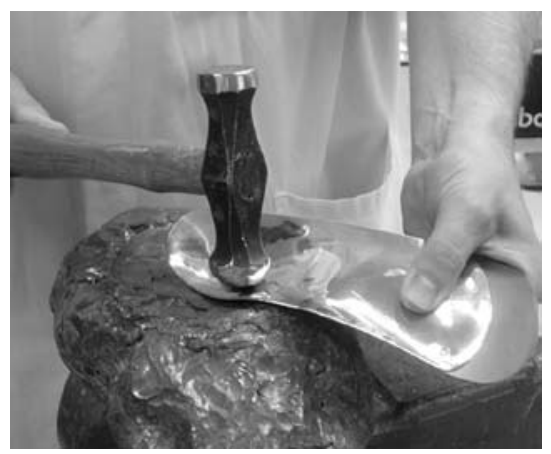

Figuur 7: Bijkloppen van een metalen steunzool op een klomp lood om de vorm aan te passen aan de wensen of noden van een patiënt. Ouderwetse methode.

Vooral hard hameren en een overtuigende presentatie van een iets anders gedeukte steunzool deed inderdaad menig patiënt opgelucht de spreekkamer verlaten.

Steunzolen voor voetproblemen leek me dan ook een uitgelezen onderzoeksveld. Het is een relevant en vaak voorkomend probleem waar basaal onderzoek vrijwel ontbreekt. Het feit dat podotherapeutische zolen destijds wel vergoed werden door ziektekostenverzekeraars, en de zolen van de instrumentmaker en schoenmaker niet was de aanleiding tot de start van een RCT (figuur 8).

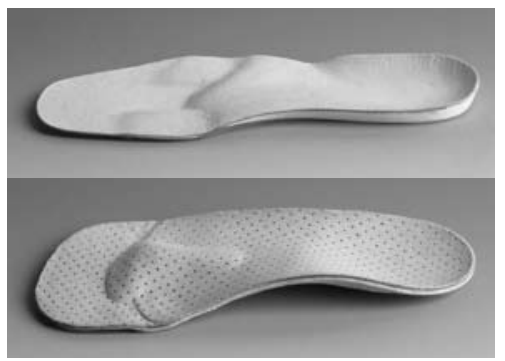

Figuur 8: Twee modernere steunzolen gemaakt door respectievelijk een podotherapeut (boven) en een orthopaedisch instrumentmaker (onder). In beide gevallen is de indicatie metatarsalgie (pijnlijk doorgezakte voorvoet). Duidelijk zichtbaar is een verschil in materiaalgebruik en vorm, gebaseerd op onder andere een verschil in filosofie hoe de correctie moet worden aangebracht. 
Wij konden daarbij in het azM beschikken over sophisticated en in Nederland zeldzame voetdrukmeetapparatuur, ook wel gebruikt bij patiënten met diabetische voetproblemen.

Het onderzoek, dat inmiddels is afgesloten, toont op onweerlegbare wijze aan dat zonder goede meetapparatuur niet kan worden vastgesteld waar de hoogste drukken onder de voet bestaan.

In Nederland worden steunzolen gemaakt door de drie genoemde beroepsgroepen. Er zijn bij het onderzoek grote verschillen in kwaliteit van de steunzolen aangetoond zowel tussen de individuele makers maar ook, en met name tussen deze drie beroepsgroepen onderling (5). Het is van belang dat niet alleen podotherapeuten als paramedisch beroep erkend zijn, maar ook de orthopaedisch instrumentmakers en schoenmakers. Net als bij Fysiotherapeuten dient een adequaat onderzoeksprogramma de professionalisering van deze vakken verder uit te bouwen, waardoor ze minder op empirie hoeven te steunen.

\section{Biomaterialen en infecties}

Ik wil overschakelen naar een meer specialistisch en high-tech onderwerp als illustratie van het vakgebied. Een goed voorbeeld daarvan is de toepassing van biomaterialen in de orthopedie.Veel materialen zijn op het ogenblik beschikbaar om na implantatie in de mens een lichaamsfunctie te ondersteunen of te vervangen, zoals de hier getoonde en meest bekende orthopaedische voorbeelden: heup- en knieprothesen. Deze prothesen zijn gemaakt van sterke metaallegeringen en kunststoffen die door het lichaam niet worden afgestoten. Het is verheugend dat het toenemend belang van biomaterialen onderzoek juist hier in de regio vorm krijgt in strategische allianties. Er bloeit een veelbelovende samenwerking op tussen onze afdeling en DSM. Er zal onderzoek worden uitgevoerd naar wervelkolomimplantaten, naar de toepassing van de Dyneema ultrasterke vezels en ook naar antibacteriële bedekking van implantaten. Het belang van dit Biomaterialen onderzoek wordt onderkend door de Universiteit, die daartoe een leerstoel "Orthopaedische Biotechnologie" instelde op onze afdeling, en ook door participatie in het landelijke programma Biomaterialen onderzoek (BMM), waarin een groot aantal kennisinstellingen en bedrijven zullen samenwerken, en waarvoor recent een groot bedrag van 45 Miljoen Euro door de regering beschikbaar is gesteld.

De zeer grote winst in kwaliteit van leven die een goed functionerende heupprothese oplevert bij een patiënt is evident en vaak aangetoond. 
Het heeft de kreupele artrotische patiënt vrijwel uit het straatbeeld gehaald, en veel ouderen vanachter de geraniums. Die zeer grote winst die deze electieve ingrepen opleveren staan in een des te groter contrast met de situatie die ontstaat als de ingreep mislukt. Ik kom daarmee op een laatste onderwerp dat mij een ruim 25-tal jaren na aan het hart ligt: de behandeling, maar met name ook de preventie van infecties in de Orthopaedie. Biomaterialen infecties zijn het duidelijkste voorbeeld hoe grote sprongen voorwaarts in de geneeskunde soms duur betaald worden met nog grotere sprongen achterwaarts.

Biomaterialen hebben de vervelende eigenschap dat bacteriën zich erop kunnen nestelen, en zich bij die fixatie eraan onbereikbaar voor afweercellen en antibiotica maken.

Direct na de implantatie van b.v. een heupprothese hechten bacteriën zich stevig aan het plastic of metaal oppervlak en omhullen zich met een ondoordringbare eiwitlaag (figuur 9).

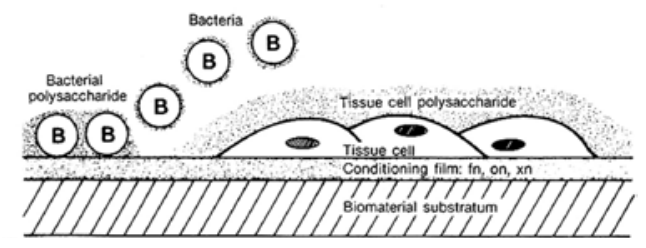

Figuur 9a: Bacteriën (B) hechten zich op een implantaat ("biomaterial substratum"), direct na de implantatie, en gaan daarbij in competitie met lichaamseigen cellen ("tissue cell") die hetzelfde proberen: de "race for the surface".

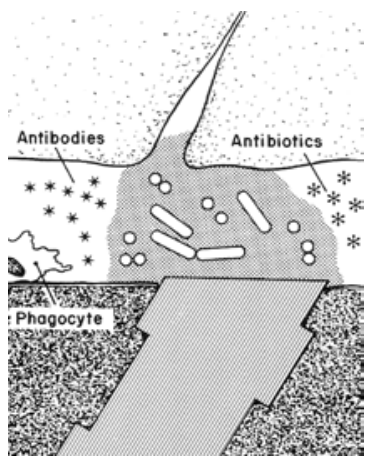

Figuur 9b: Schematische weergave van een schroef in bot. Bacteriën hebben zich aan de schroef gehecht en zich daarbij ook omgeven met een eiwitlaag. Ze zijn daardoor onbereikbaar voor de afweer (phagocyten, antilichamen en antibiotica) en kunnen zich ongestoord vermeerderen. 
In de uren direct daarna vermenigvuldigen de bacteriën zich snel. Zo kan er een diepe wondinfectie ontstaan, waardoor de prothese wordt bedreigd.

Hoe erg is nu een prothese infectie ? Het betekent langere opnameduur, gebruik van veel antibiotica, meestal meerdere grote operaties, en veel hogere kosten. Erger is dat bij een belangrijk deel van de patiënten de prothese moet worden verwijderd (figuur 10).

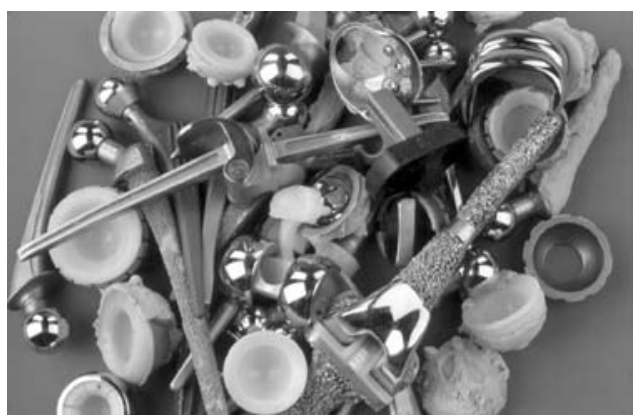

Figuur 10: Een verzameling verwijderde heup- en knieprothesen in verband met loslating en infectie. De meeste orthopaeden bouwen wel zo'n voorraad op tijdens hun carrière.

Lang niet altijd kan een hernieuwde plaatsing na geruime tijd volgen. Dat betekent dat een electieve ingreep, bedoeld om een patiënt mobiliteit te geven en pijn weg te nemen, uitloopt op een vaak pijnlijke en steeds invaliderende situatie zonder de beoogde gewrichtsfunctie. Gebruik van krukken en rolstoel voor de rest van het leven (figuur 11).

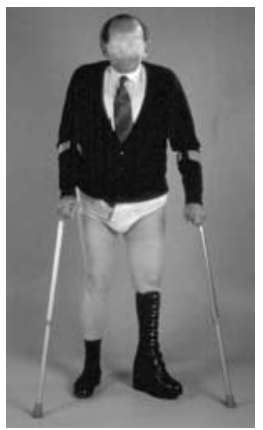

Figuur 11: Patiënt waar links na een aantal operaties in verband met infectie van een heup prothese niet meer een prothese kon worden terug geplaatst. Het been is circa $6 \mathrm{~cm}$ verkort, waarvoor een zoolverhoging onder de orthopaedische schoen gedragen moet worden. Omdat de steun en kracht rond de heup ontbreekt is gebruik van 2 krukken nodig, levenslang. 
Is een prothese infectie dan frequent ? Indien alle maatregelen adequaat genomen worden kan het diepe infectiepercentage bij gewrichtsprothesen onder $1 \%$ blijven. Dat geeft de internationale literatuur aan, en voor Nederland wordt dat bevestigd door het zeer waardevolle landelijke surveillance programma van CBO en RIVM voor postoperatieve wondinfecties: PREZIES (tabel 1).

202.779 geregistreerd totaal aantal operaties

$6.056 \quad$ total aantal diepe wondinfecties

waarvan:

$\begin{array}{llll}20.779 & \text { totale heupprothesen } & 1,0 \% & \text { diepe infecties } \\ 10.722 & \text { totale knieprothesen } & 0,9 \% & \text { diepe infecties } \\ 2.688 & \text { kophalsprothesen } & 2,8 \% & \text { diepe infecties }\end{array}$

Tabel 1: Aantallen operaties en infecties geregistreerd in het landelijke surveillance programma voor postoperatieve wondinfecties PREZIES (CBO en RIVM) in 83 ziekenhuizen. (1997-2006). Ook de gegevens voor totale heup, totale knie en kophals prothesen: alleen de diepe infecties en voorzover gebruik is gemaakt van surveillance na ontslag zoals geadviseerd.

Bij kophalsprothese plaatsingen vinden we landelijk echter een diep infectiepercentage van $2,8 \%$ in plaats van $1 \%$ dat ook in deze patiënten haalbaar zou moeten zijn (11). Het gaat hierbij weliswaar om oudere, zwakkere en vaak ernstig zieke patiënten met een verhoogde infectie kans, maar juist dit percentage bij deze patiëntengroep geeft aan of de kwaliteit van de zorg wel optimaal is. Het kan dus in Nederland beter.

De hoeveelheid bacteriën die in de operatiekamerlucht circuleren is voor het ontstaan van wondinfecties van doorslaggevend belang omdat die concentratie in de lucht bepaalt hoeveel bacteriën in de wond kunnen komen. Die bacteriën worden vrijwel alleen in de OK lucht gebracht door de mensen die op de OK werken. Het is goed mogelijk met strenge discipline en goede kleding het aantal bacteriën in de lucht te beperken, maar dat is niet voldoende.

Met al lang beschikbare techniek is het mogelijk de gecontamineerde lucht op de OK weg te voeren en het operatiegebied te voorzien van schone, bacterievrije lucht (figuur 12). 


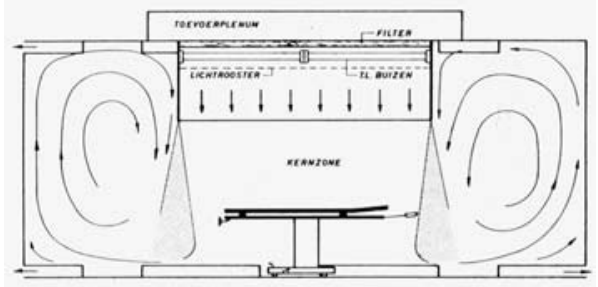

Figuur 12a: schema van niet mengend systeem waarbij laminaire lucht op de operatiekamer met een snelheid van circa $30 \mathrm{~cm} / \mathrm{sec}$ wordt ingeblazen vanuit het plafond (downflow), en daartoe nog ongeveer een meter wordt geleid door een randafscherming. Zijdelings aangezicht.

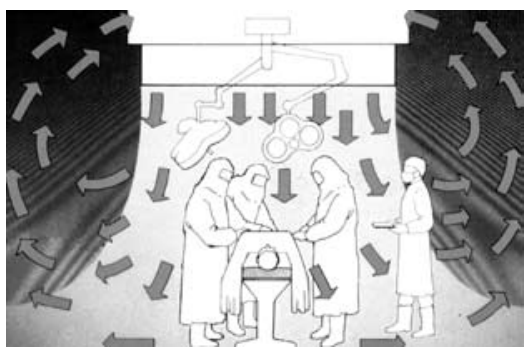

Figuur 12b: Schema van een zogenaamde "exponentiele flow" waarbij de lucht met vooral centraal hoge snelheid wordt ingeblazen om een gegarandeerde en stabiele downflow te kunnen verkrijgen. De schone lucht voert alle kleine gestrooide besmette partikels weg van de operatietafel. Het operatieteam kan zich nog extra isoleren door gebruik te maken van helmen.

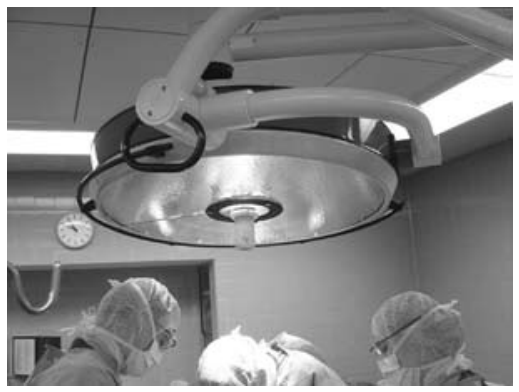

Figuur 12c: Voorbeeld van een ouderwets, mengend luchtbehandeling systeem waar geen downflow bestaat. Als er wel een neergaande luchtstroom vanuit het plafond zou zijn geweest, was die echter geheel tegengehouden door de grote, dichte lamp zonder aërodynamische vormgeving. 
Deze techniek wordt sinds 20 - 30 jaar uitgebreid toegepast in de voedingsmiddelen-industrie, pharma- en elektronica- industrie. Het lijkt logisch lijkt om deze techniek dus overal op operatiekamers door te voeren. Inderdaad is dat al op veel plaatsen het geval en sinds kort is dit voor nieuwbouw van ziekenhuizen ook het advies van het College bouw ziekenhuisvoorzieningen (2). In bestaande ziekenhuizen echter zijn de kosten van verbouw in combinatie met een soms kortzichtige budgettaire benadering niet zelden een belemmering voor broodnodige verbetering hierin.

Om te komen tot betere adviezen over luchtbehandeling op operatiekamers in Nederland kwamen na uitnodiging van veel beroepsgroepen sinds 1998 hygiënisten, technici, ingenieurs en medici bijeen. Zij werden daarbij krachtig en effectief gesteund door de Hoofdinspectie van de Volksgezondheid. Het bleek weerbarstige materie, maar het lukte uiteindelijk te komen tot de formulering van een "Beheersplan Luchtbehandeling voor de operatieafdeling" (14). Daarin staat geformuleerd hoe in de ziekenhuizen het beheer dient te worden georganiseerd. Er moet een plan van aanpak en controle via de zogenaamde HACCP methode worden ontwikkeld, er wordt beschreven hoe het technische functioneren van de installatie moet worden gecontroleerd, en in het Beheersplan staan tot slot adviezen voor het technisch ontwerp. Ik mocht als laatst fungerend voorzitter van de stuurgroep het plan in maart 2005 overhandigen aan de Inspecteur Generaal. Het Beheersplan wordt nu geleidelijk aan in Nederland ingevoerd en is toegevoegd aan de betreffende WIP richtlijn. De inspectie vraagt de ziekenhuizen naar de invoering ervan bij haar inspectieronde die nu naar de peri-operatieve processen in Nederland wordt uitgevoerd. In November zullen we in een congres de vorderingen in Nederland evalueren.

Er bestaan toch in Nederland nog een aanzienlijk aantal operatiekamer complexen die sterk verouderd zijn, en die een verouderde luchttechniek hebben. Nu worden de meeste orthopeden erg zenuwachtig als hun verpleegafdeling geleidelijk aan bezet raakt met diepe infecties van gewrichtsprothesen. Regelmatig krijg ik dus telefoon van een collega orthopaed die het benauwd krijgt van de opduikende infecties. Hij kan zich dan gelukkig prijzen als hij een goede infectieregistratie heeft, vaak doordat er een hygiënist in het ziekenhuis fungeert van het goede soort. Schrikbarend is dat dan soms toch al enige tijd diepe infectiepercentages van prothesen blijken te bestaan van 5 tot $10 \%$, in plats van minder dan $1 \%$. Helaas is het dan vervolgens inderdaad zo dat een installatie 
vernieuwen kostbaar is. Soms zijn er verbouw- of nieuwbouwplannen, meestal echter pas in de verre toekomst. Beslissingen worden dan soms weggeschoven, en problemen ontkend. Totdat zoals in een groot Brabants ziekenhuis het geval was, op gezag van de inspectie de OK's acuut gesloten moesten worden en een dure tijdelijke oplossing nodig was: 2 nood OK's tegen de gevel voor 2 miljoen euro.

Dit is een extreem voorbeeld, maar in Nederland op het ogenblik niet uniek.

\section{Conclusie}

Mijnheer de rector, dames en heren

Ik heb getracht $U$ een inzicht te geven in de mogelijkheden van een boeiend vak, dat zich richt op een groot scala van problemen van het BA, van klein tot groot, van eenvoudig tot complex. We proberen iedereen zo goed, zo lang mogelijk te laten bewegen, vandaar het adagium "blijft in beweging". Als orthopeden realiseren we ons ook dat de inhoud van ons vak voortdurend verandert en dat de grensgebieden fluctueren, in die zin beweegt Orthopaedie evenzeer.

Bewegen is ook in, het is voor alles goed. Bij het betrekken van het pas gebouwde huidige ziekenhuis in 1991 was een nieuw logo ontworpen waarin samenwerking en dynamiek tot uiting werd gebracht, een logo dat veel weg had van een logo dat ik zelf eind jaren zeventig gebruikte om gentamicinekralen af te beelden.

Daarna is in het azM bewegen opnieuw tot mijn genoegen het belangrijkste onderwerp geworden.Immers, de beweging tot hernieuwde motivatie van alle medewerkers bij het aantreden van Guy Peeters kreeg de naam azMove (figuur 13).

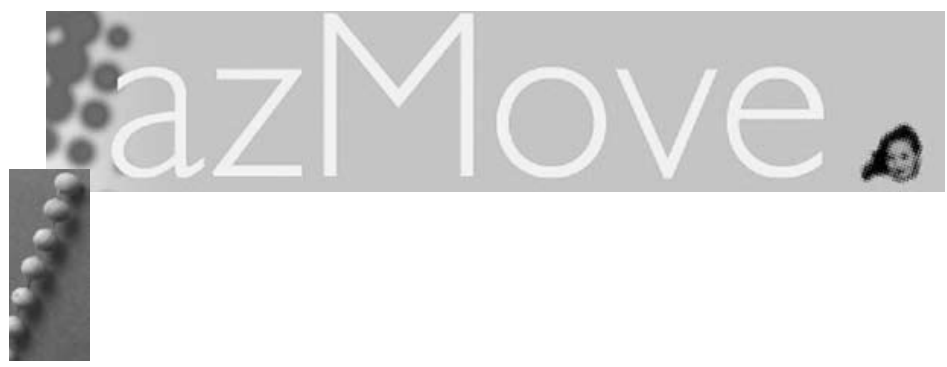

Figuur 13: azM move logo, met door de auteur suggestief toegevoegde antibioticum kralen. 
Bij het vertrek van Servé Kuijer was bewegen vervolgens opnieuw het centrale thema. Tot slot is de komende jaren in de nieuwe Maastricht UMC+ een belangrijk thema: "Sport, Bewegen en Lifestyle". Wij hopen daar als afdeling Orthopaedie onze specifieke kennis en kunde in te kunnen zetten. Wij zullen dan $U$ kunnen helpen bij het motto dat ik deze rede meegaf: "Blijft in Beweging".

Dames en heren.

Toen La Chapelle in 1954 zijn inaugurale rede als lector in Utrecht hield was ik zeven jaar en de inhoud van zijn rede heb ik moeten lezen. Hier en daar staat wat opmerkelijks. Zo verzucht hij op pagina 6 dat hij een uur moet volpraten. Ik hoop niet dat $U$ de indruk kreeg dat ik daar veel moeite mee had. Wat meer van toepassing zou kunnen zijn, is dat hij zijn rede begint met de volgende passage:

"Het wordt mij heden, door de omstandigheden, gegeven een openbare les te houden op een leeftijd, die er naar neigt zich te beraden op een afscheidscollege. Het zij zo".

Hij was toen 66 jaar, maar dat was niet zò bijzonder, als ik kijk naar andere leeftijden: Mulder was 60 jaar, net als Kingma, Chapchal was 59 jaar en Verbeek was ook 66 jaar.

Aan het einde van mijn rede gekomen wil ik graag de gelegenheid te baat nemen enkelen te bedanken.

Allereerst de besturen van de universiteit en faculteit. Ik ben ze dankbaar voor het in mij gestelde vertrouwen en voor de constructieve wijze waarop mede vorm is gegeven aan de wens de afdeling Orthopaedie vastere voet te laten herkrijgen in de facultaire organisatie. Ik zal dan ook alle mogelijkheden die de universitaire omgeving biedt aangrijpen. We zullen in de opleiding van de studenten het BA zo optimaal mogelijk aan bod laten komen, en willen komen tot steviger verankering van het onderzoek in de facultaire thematiek. We hopen dan ook dat de goede contacten met de instituten zullen leiden tot structurele en substantiële samenwerking. Wij zijn gelukkig met de inbedding van ons patiëntgebonden onderzoek in het deelprogramma "Bewegingsappraat" (prof.dr. Rob de Bie) van de School Public Health and Primary Care: Caphri (prof.dr. Guy Widdershoven en prof.dr. Onno van Schayck). In dit instituut zijn we als vakgroep preferent ondergebracht. De wederzijdse positieve opstelling en de productieve samenwerking rechtvaardigen ons optimisme voor de toekomst. Het meer basale preklinische onderzoek zoekt een innesteling in Grow (prof.dr. Piet Brand) en/of in Nutrim (prof. dr. Annemie Schols). Wij zien de academische patiëntenzorg een ideale 
inbedding krijgen in de zorgketen "Chronische ziekten" (prof.dr. Emiel Wouters).

Wij nemen aan dat bij het zogenaamde "maken van keuzes" bestuurders van universiteit en ziekenhuis zich ook en wellicht meer laten leiden door de "social impact" en genoemde gezondheidsmaten van vaak voorkomende ziekten, meer dan door historische keuzes uit het verleden en gefixeerde belangen.

Het bestuur van het azM heeft een bijzondere rol gespeeld bij het revitaliseren van de afdeling Orthopedie, en met name Servé Kuijer. Hij heeft tot aan de laatste dagen (en uren) vóór zijn vertrek met grote inzet en volharding de visie van het bestuur vorm gegeven, waarbij met name de inzet van beschikbare menselijk kapitaal voorop stond. Er is gekozen voor een snelle doorstart en om gebruik te maken van de vele positieve en vernieuwende krachten waarmee de afdeling zich al sinds lang in het azM heeft geprofileerd. We zijn nu in staat met de juiste mensen op de juiste plaats de afdeling optimaal te laten functioneren en zijn vol vertrouwen in de toekomst.

De vakgroep Orthopaedie bestaat uit een aantal al zeer lang samenwerkende orthopaeden en een aantal die zich recent bij ons heeft gevoegd. Samen willen we de grote groep patiënten die zich tot ons wendt optimale zorg bieden, niet alleen diegenen die onze last resort functies zoeken, maar ook de regionale, Maastrichtse bevolking die recht heeft op adequate en goed toegankelijke orthopaedische zorg in hun eigen regio. Wij vinden de $40-60 \%$ een zinvolle en rechtvaardige verdeling in die twee soorten van zorg.

We hebben onze gezondheidszorg, onderwijs en onderzoek steeds zo enthousiast en goed mogelijk gedaan. We deden dat steeds vooral ook eensgezind en in prima verstandhouding gedaan. We hebben nu nieuwe kansen gekregen, en die willen we in dezelfde goede verstandhouding ook geheel benutten. Ik zal mijn best doen jullie daarin zo goed mogelijk te faciliteren. Ook alle andere medewerkers van de afdeling dank ik voor de vaak al 25 jaar durende samenwerking, maar ook als het korter was.

Wij wonen en werken nu sinds ruim 25 jaar in Maastricht. Zowel de woon- alsook de werkomgeving heeft ons steeds geïnspireerd. Zoals gebruikelijk is een aantal familieleden helaas overleden, maar een ruim aantal kennissen en vrienden gebleven. Wij hebben een groot aantal dierbare herinneringen aan velen, ook hier in de zaal. Wij zijn van plan daar nog veel aan toe te voegen.

Ik heb gezegd. 


\section{Referenties}

1. Bakker LF. Nederlandse Orthopaedische Vereniging 1898 - 1998. De geschiedenis van de Orthopaedie in Nederland. 1998.

2. College bouw ziekenhuisvoorzieningen. Operatieafdeling. Bouwmaatstaven voor nieuwbouw. en: Referentiekader ten behoeve van bestaande operatieafdelingen. 2004.

3. Ed: PJ Kuijer etal. Nederlandse Vereniging voor Heelkunde 1902 - 1977. Gedenkboek. 1977.

4. Fournier M. De medico-mechanische toestellen van dokter Zander. Museum Boerhaave Leiden; 1989.

5. Guldemond NA, Leffers P, Nieman FHM, Sanders AP, Schaper NC and Walenkamp GHIM. Testing the proficiency to distinguish locations with elevated plantar pressure within and between professional groups of foot therapists. BMC Musculoskeletal Disorders 2006; www..biomedcentral. com/1471-2474/7/93.

6. Hillen HFP and Peeters GJHCM. Focus en Ketens. Onderzoek en Topreferente zorg in Maastricht $\mathrm{UMC}^{+} .2007$.

7. Horst van der $\mathrm{H}$. Een ondergeschoven kindje. Te weinig aandacht voor alledaagse klachten en kwalen. Medisch Contact 2006; 61 (10): 412-414.

8. Kampen van A. Orthopaedische Traumatologie van A tot Z. Rede uitgesproken bij de aanvaarding van het ambt van hoogleraar in de Orthopaedische traumatologie. Nijmegen; 2002.

9. Nationaal Kompas Volksgezondheid. Artrose. Omvang van het probleem. website www.nationaalkompas.nl 2007.

10. Nationaal Kompas Volksgezondheid. Ziekten en aandoeningen. website www.nationaalkompas.nl 2007.

11. PREZIES. Prezies landelijk netwerk ziekenhuisinfecties. Module postoperatieve wondinfecties, referentiecijfers 1997 - 2006. http://www.prezies.nl/powi/ ref_cijfers.html 2007.

12. Raad voor Gezondheidsonderzoek. Onderzoeksagenda Medische Biotechnologie. Den Haag: Raad voor gezondheidszorgonderzoek; 2006.

13. Santen van H. Minder geld voor gewone kwalen. Subsidiestop dreigt voor onderzoek naar alledaagse aandoeningen. In: editor. NRC Handelsblad, Wetenschapskatern; 2007. p. 9.

14. Stuurgroep en werkgroepen "Beheersplan". Beheersplan Luchtbehandeling voor de operatieafdeling. www.vccn.nl ; www.nov.org ; www.vhig.nl ; www.wip.nl 2005.

15. tns nipo enquete. Bewegen = meedoen. In: editor. presentatie NOV najaarscongres Veldhoven; 12 oktober 2007.

16. Treurniet HF, Hoeymans N, Gijsen R and Poos MJJ. Gezondheid en ziekte in Nederland; het Nationaal Kompas Volksgezondheid als informatiebron. Ned Tijdschr Geneeskd 2005; 149 (5): 226-231.

17. Verhaar JAN. Tennis elbow. Maastricht: University of Maastricht; 1992. 


\section{Afkortingen}

azM

BA

CBO

HACCP

PREZIES

RCT

RIVM

UMC+

WIP academisch ziekenhuis Maastricht Bewegingsapparaat

Kwaliteitsinstituut voor de gezondheidszorg Hazard Analysis of Critical Control Points

Preventie van Ziekenhuisinfecties door Surveillance Randomised Clinical Trial

Rijksinstituut voor Volksgezondheid en Milieu

Universitair Medisch Centrum (plus: inclusief Gezondheidswetenschappen)

Werkgroep Infectie Preventie 
